\title{
Facial necrotic ulcerative lesions in an adolescent female with granulomatosis with polyangiitis (GPA)
}

\author{
Lampros Fotis $^{1}$ (D) Spyridon Prountzos ${ }^{2} \cdot$ Georgia Giannouli $^{1} \cdot$ Vassiliki Papaevangelou $^{1}$
}

Received: 21 April 2020 / Revised: 21 June 2020 / Accepted: 23 June 2020 / Published online: 1 July 2020

(C) International League of Associations for Rheumatology (ILAR) 2020

\section{Case presentation}

A 15-year-old female was referred with forehead lesions starting 3 months before, initially treated as acne. She was also suffering from recurrent otitis media, treated with 3 courses of antibiotics over the last 45 days. Four weeks ago, she was admitted to another institution with symptoms of arthralgias, myalgias, and low-grade fever up to $37.8^{\circ} \mathrm{C}$. Her physical exam revealed ulcerative lesions of the forehead (Fig. 1) and pre-auricular area bilaterally, muscle tenderness, hemorrhagic lesions of the nasal mucosa, aphthous ulcers of the buccal mucosa, gum hemorrhagic lesions, right side perforated tympanic membrane, and otorrhea. No sinusitis, rhinitis, or chronic cough was ever reported. Blood pressure was 115/78 $\mathrm{mmHg}$. Chest $\mathrm{X}$-ray revealed nodular lesions and CT chest confirmed the presence of 2 large nodular lesions up to $1.5 \mathrm{~cm}$ of diameter as well as multiple smaller nodules (Fig. 2). The paranasal sinuses imaging revealed mastoid cells, sphenoid sinus, and the ethmoid cells filled with secretions, with demineralization of the septations of the latter. Forehead skin lesion biopsy revealed ulcerative lesions with fibroinflammatory exudate and granulomatous reaction of the dermis, but no lesions suggestive of vasculitis. Blood testing revealed WBC $11360 / \mu \mathrm{L}(\mathrm{Ne}$ $65.5 \%$, Ly $23 \%$, Mo $8.1 \%$, Eo $3.3 \%$ ), Hb $11.3 \mathrm{~g} / \mathrm{dl}$, PLT $374 \mathrm{~K} / \mu \mathrm{L}$, CRP $91.8 \mathrm{mg} / \mathrm{L}$, ESR $140 \mathrm{~mm} / \mathrm{h}$, Ur $24 \mathrm{mg} / \mathrm{dL}, \mathrm{Cr} 0.5 \mathrm{mg} / \mathrm{dL}$, AST $10 \mathrm{U} / \mathrm{L}$, ALT $7 \mathrm{U} / \mathrm{L}$, and CPK $23 \mathrm{U} / \mathrm{L}$. Urine protein/creatinine ratio was $<0.2$, and

Lampros Fotis

lampros.fotis@outlook.com

1 Department of Pediatrics, Attikon General Hospital, National and Kapodistrian University of Athens, 1 Rimini Str. 12462 Athens Greece

2 Department of Radiology, Attikon General Hospital, National and Kapodistrian University of Athens, Athens Greece urinalysis was negative for hematuria. ANCA indirect immunofluorescence was positive (c-ANCA) with PR-3 specificity $(300 \mathrm{U} / \mathrm{mL})$ by ELISA. The diagnosis of granulomatosis with polyangiitis (GPA) was established and she was treated with IV methylprednisolone pulses $(1 \mathrm{~g} \times$ 3 days) followed by $60 \mathrm{mg} /$ day with a tapering dose and rituximab $500 \mathrm{mg} \times 4$ doses.

\section{Discussion}

In GPA, the prevalence of skin disease has been reported to range between 35 and $50 \%$ and can be the first manifestation in up to $8 \%$ of cases [1]. Skin involvement is reported in $48 \%$ of all pediatric patients with ANCAassociated small vessel vasculitis. In GPA most frequently includes palpable purpura and/or petechial rash $(27 \%)$, subcutaneous nodules (8\%), infarctions (3\%), livedo (1\%), Raynaud's phenomenon (3\%), and subcutaneous swelling (3\%) and is often polymorphic [2], very similar to the prevalence in adult studies [3, 4]. Necroticulcerative lesions most commonly occur on the extremities but may also occur on the face and scalp [5]. Acneiform and folliculitis-like papules have been described in patients younger than 20 years of age, often

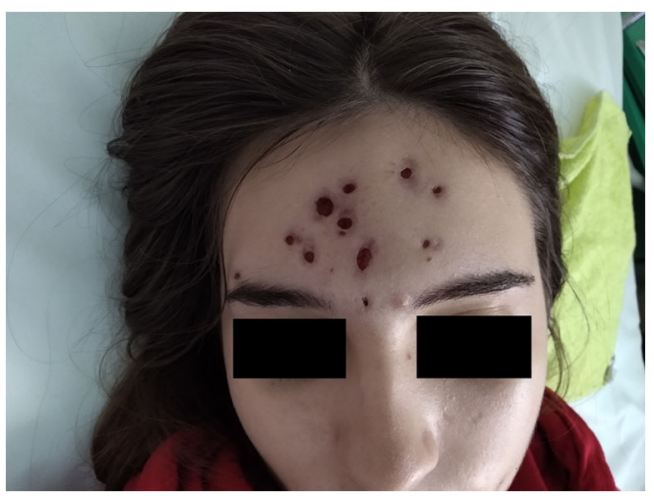

Fig. 1 Ulcerative lesions of the forehead 


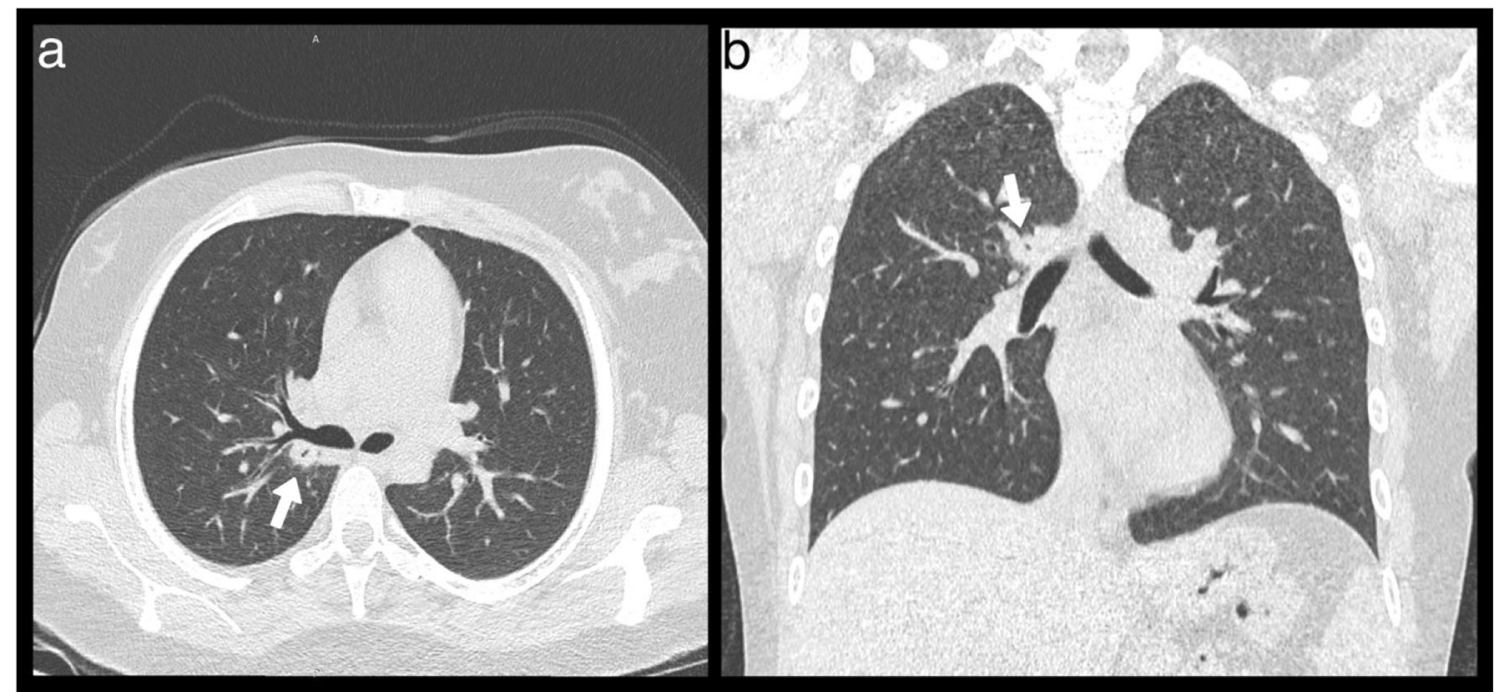

Fig. 2 a Axial and b coronal plane reconstructed CT scan images showing a cavitating pulmonary nodule underneath the right main bronchus (white arrow)

occurring as the initial presenting symptom [1]. Other than acne and folliculitis, pyoderma gangrenosum and other neutrophilic dermatosis, infections, malignancies, and systemic connective tissue disease are included in the differential diagnosis of similar type lesions $[1,5]$.

\section{Compliance with ethical standards}

\section{Disclosures None.}

Consent for publication We obtained written informed consent from the patient and her parents for publication of this case report together with any accompanying images.

\section{References}

1. Wright AC, Gibson LE, Davis DMR (2015) Cutaneous manifestations of pediatric granulomatosis with polyangiitis: a clinicopathologic and immunopathologic analysis. J Am Acad Dermatol 72:859 867. https://doi.org/10.1016/j.jaad.2015.01.043

2. Cabral DA, Canter DL, Muscal E, Nanda K, Wahezi DM, Spalding SJ, Twilt M, Benseler SM, Campillo S, Charuvanij S, Dancey P, Eberhard BA, Elder ME, Hersh A, Higgins GC, Huber AM, Khubchandani R, Kim S, Klein-Gitelman M, Kostik MM, Lawson
EF, Lee T, Lubieniecka JM, McCurdy D, Moorthy LN, Morishita KA, Nielsen SM, O'Neil KM, Reiff A, Ristic G, Robinson AB, Sarmiento A, Shenoi S, Toth MB, van Mater HA, Wagner-Weiner L, Weiss JE, White AJ, Yeung RSM, the ARChiVe Investigators Network within the PedVas Initiative (2016) Comparing presenting clinical features in 48 children with microscopic polyangiitis to 183 children who have granulomatosis with polyangiitis (Wegener's): an ARChiVe cohort study. Arthritis Rheumatol 68:2514-2526. https:// doi.org/10.1002/art.39729

3. Micheletti RG, Chiesa Fuxench Z, Craven A et al (2020) Cutaneous Manifestations of Anti-Neutrophil Cytoplasmic AntibodyAssociated Vasculitis. Arthritis Rheumatol (Hoboken, NJ). https:// doi.org/10.1002/ART.41310

4. Frumholtz L, Laurent-Roussel S, Aumaître O, Maurier F, le Guenno G, Carlotti A, Dallot A, Kemeny JL, Antunes L, Froment N, Fraitag S, London J, Berezne A, Terris B, le Jeunne C, Mouthon L, Aractingi S, Guillevin L, Dupin N, Terrier B, French Vasculitis Study Group (2017) Clinical and pathological significance of cutaneous manifestations in ANCA-associated vasculitides. Autoimmun Rev 16:11381146. https://doi.org/10.1016/j.autrev.2017.09.009

5. Marzano AV, Raimondo MG, Berti E, Meroni PL, Ingegnoli F (2017) Cutaneous manifestations of ANCA-associated small vessels vasculitis. Clin Rev Allergy Immunol 53:428-438. https://doi.org/ 10.1007/s12016-017-8616-5

Publisher's note Springer Nature remains neutral with regard to jurisdictional claims in published maps and institutional affiliations. 